\title{
Formulation, Evaluation and Characterization of Itraconazole Lozenges
}

\author{
Deepika modyala $^{1}$, C. Aparna ${ }^{1 *}$, Prathima Srinivas $^{1}$ \\ ${ }^{I}$ (Department of Pharmaceutics, Sri Venkateshwara College of Pharmacy, Affiliated to Osmania University, \\ Madhapur, Hyderabad-500081, Andhra Pradesh, India)
}

\begin{abstract}
Candidiasis, caused by Candida albicans, is an extremely common, local fungal infection but can become systemic and life-threatening in immune-compromised patients. Itraconazole has been used for prophylaxis and treatment of invasive fungal diseases, such as candidiasis and aspergillosis for the last two decades. The present work is aimed to formulate different types of lozenges for topical delivery of Itraconazole for the treatment of oropharyngeal candidiasis. Compressed tablet lozenges were prepared by wet granulation technique using three different binders, at different concentrations. Soft lozenges (hand-rolled and PEG-base) lozenges were formulated using different excipients. They were evaluated for post-compression parameters by pharmaceutical standard methods. Stability studies were carried out according to ICH guidelines. The optimized formulations were subjected to microbial studies to see their antimycotic activity. The formulated lozenges were evaluated for physical parameters and the results complied with the pharmacopeial limits. In vitro dissolution studies showed $90 \%$ drug release by the end of 60 min. FTIR studies showed that there were no drug-excipient interactions. Stability studies indicated that the formulations were stable for 3 months and no significant drug degradation was observed. Itraconazole lozenges were successfully formulated and evaluated. The formulations were successful in delivering the drug for topical application.
\end{abstract}

Key terms: Compressed tablet lozenges, hand rolled lozenges, oropharyngeal candidiasis, PEG base lozenges, soft lozenges.

\section{Introduction}

Candidiasis, especially that caused by Candida albicans, is extremely common; however, it is not clear why these usually harmless commensal organisms become pathogenic. Candidiasis can occur in most parts of the body. Infection is particularly common in young children and elderly people following antibiotic treatment. People with diabetes and suppressed immune systems are also vulnerable to candidiasis. Most infections are local, but for immune-suppressed patients they can become systemic and life-threatening, especially if they are infected with a drug-resistant strain. $[1,2,3]$ The choice of antifungal agent used in the treatment of candidiasis is dependent upon the severity and nature of the infection. [4] In case of local infections, only topical therapy is preferred and in case of systemic infections, a combination of topical and systemic therapies is used as treatment regimen. [5]

Itraconazole (ITZ), a broad-spectrum antimycotic triazole has been used for both prophylaxis and treatment of invasive fungal diseases, such as candidiasis and aspergillosis for the last two decades. ITZ is classified as a class II drug according to the Biopharmaceutical Classification System. It has an extremely low aqueous solubility $(\mathrm{S}<1 \mu \mathrm{g} / \mathrm{ml})$ and poor dissolution rate in the gastrointestinal tract and hence low and variable bioavailability.

The present study involves formulation of Itraconazole lozenges for topical therapy of oropharyngeal candidiasis. Lozenges are the flavored medicated dosage forms intended to be sucked and held in the mouth or pharynx containing one or more medicaments usually in the sweetened base. Lozenges are intended to relieve oropharyngeal symptoms, which are commonly caused by local infections. Topical application of drug prevents several drug interactions. Lozenges are considered to be better delivery system as the effective concentrations of the drug can be maintained in the oral cavity for a prolonged period as the lozenge is sucked slowly in the mouth. $[6,7,8,9,10]$

\subsection{Materials}

\section{Materials And Methods}

Itraconazole was kindly supplied as a gift sample from Cornelius Pharmaceuticals (p) Ltd. Hyderabad, India; Sucrose, Gelatin, PEG 1500, Sodium lauryl sulphate by s d fine-chem Limited; Acacia, tragacanth, PEG 400, Sodium hydroxide, Potassium phosphate, monobasic by Finar chemicals Limited; PEG 4000 by Loba Chemie Pvt. Ltd. Sucralose by Natura. All other chemicals were of analytical grade. 


\subsection{Methods}

\subsubsection{Analytical method development}

2.2.1.1 Determination of $\lambda \max$ of Itraconazole in methanol

A $10 \mu \mathrm{g} / \mathrm{ml}$ standard solution of Itraconazole in methanol was scanned on a double beam UV spectrophotometer. From the UV spectrum of Itraconazole, $\lambda_{\max }$ was obtained.

2.2.1.2 Determination of $\lambda_{\max }$ of Itraconazole in $\mathrm{pH} 6.8$ phosphate buffer with various concentrations of SLS Itraconazole is soluble at acidic $\mathrm{pH}$ and has minimal solubility at neutral $\mathrm{pH}$. While performing invitro drug release studies the amount of drug present in the sample could not be detected because of the solubility problem. Hence sodium lauryl sulphate (SLS) was added to increase the solubility of Itraconazole in $\mathrm{pH} 6.8$ buffer. Various concentrations like $0.1 \%, 0.5 \%, 1 \%, 1.5 \%$ and $2 \%$ were tried to optimize the concentration of SLS to be added.

\subsubsection{Formulation of different types of Itraconazole lozenges}

\subsubsection{Formulation of compressed tablet lozenges}

Compressed tablet lozenges were prepared by wet granulation method. Accurately weighed amount of Itraconazole was added in small parts to sucrose and mixed thoroughly. This was granulated using binder solution (different concentrations of gelatin, acacia and tragacanth). The granules obtained were passed through sieve \#16 and then dried. The dried granules retained on the sieve \#18, along with $15 \%$ fines were mixed with weighed amounts of lubricant and glidant and were compressed in machine with maximum force to obtain a compact flat faced tablet lozenges. Color and flavor were added to the binder solution. (TABLES 1-3) (Fig. 1)

TABLE 1: FORMULATIONS WITH GELATIN AS BINDER

\begin{tabular}{|c|c|c|c|c|c|c|}
\hline Ingredient & F1 & F2 & F3 & F4 & F5 & F6 \\
\hline Sucrose & $890 \mathrm{mg}$ & $890 \mathrm{mg}$ & $890 \mathrm{mg}$ & $890 \mathrm{mg}$ & $890 \mathrm{mg}$ & $890 \mathrm{mg}$ \\
\hline Drug & $100 \mathrm{mg}$ & $100 \mathrm{mg}$ & $100 \mathrm{mg}$ & $100 \mathrm{mg}$ & $100 \mathrm{mg}$ & $100 \mathrm{mg}$ \\
\hline $\begin{array}{l}\text { Gelatin solution (concentration, } \\
\mathrm{w} / \mathrm{v})\end{array}$ & $2.5 \%$ & $5 \%$ & $7.5 \%$ & $10 \%$ & $12.5 \%$ & $15 \%$ \\
\hline Talc & $5 \mathrm{mg}$ & $5 \mathrm{mg}$ & $5 \mathrm{mg}$ & $5 \mathrm{mg}$ & $5 \mathrm{mg}$ & $5 \mathrm{mg}$ \\
\hline Magnesium stearate & $5 \mathrm{mg}$ & $5 \mathrm{mg}$ & $5 \mathrm{mg}$ & $5 \mathrm{mg}$ & $5 \mathrm{mg}$ & $5 \mathrm{mg}$ \\
\hline Color & q.s & q.s & q.s & q.s & q.s & q.s \\
\hline Flavor & q.s & q.s & q.s & q.s & q.s & q.s \\
\hline
\end{tabular}

TABLE 2: FORMULATIONS WITH ACACIA AS BINDER

\begin{tabular}{|c|c|c|c|c|}
\hline Ingredient & F7 & F8 & F9 & F10 \\
\hline Sucrose & $890 \mathrm{mg}$ & $890 \mathrm{mg}$ & $890 \mathrm{mg}$ & $890 \mathrm{mg}$ \\
\hline Drug & $100 \mathrm{mg}$ & $100 \mathrm{mg}$ & $100 \mathrm{mg}$ & $100 \mathrm{mg}$ \\
\hline Conc. of Acacia solution & $10 \%$ & $15 \%$ & $20 \%$ & $25 \%$ \\
\hline Talc & $5 \mathrm{mg}$ & $5 \mathrm{mg}$ & $5 \mathrm{mg}$ & $5 \mathrm{mg}$ \\
\hline Magnesium stearate & $5 \mathrm{mg}$ & $5 \mathrm{mg}$ & $5 \mathrm{mg}$ & $5 \mathrm{mg}$ \\
\hline Color & q.s & q.s & q.s & q.s \\
\hline Flavor & q.s & q.s & q.s & q.s \\
\hline
\end{tabular}

TABLE 3: FORMULATIONS WITH TRAGACANTH AS BINDER

\begin{tabular}{|c|c|c|c|c|}
\hline Ingredient & F11 & F12 & F13 & F14 \\
\hline Sucrose & $890 \mathrm{mg}$ & $890 \mathrm{mg}$ & $890 \mathrm{mg}$ & $890 \mathrm{mg}$ \\
\hline Drug & $100 \mathrm{mg}$ & $100 \mathrm{mg}$ & $100 \mathrm{mg}$ & $100 \mathrm{mg}$ \\
\hline Conc. of tragacanth solution & $10 \%$ & $15 \%$ & $20 \%$ & $25 \%$ \\
\hline Talc & $5 \mathrm{mg}$ & $5 \mathrm{mg}$ & $5 \mathrm{mg}$ & $5 \mathrm{mg}$ \\
\hline Magnesium stearate & $5 \mathrm{mg}$ & $5 \mathrm{mg}$ & $5 \mathrm{mg}$ & $5 \mathrm{mg}$ \\
\hline Color & q.s & q.s & q.s & q.s \\
\hline Flavor & q.s & q.s & q.s & q.s \\
\hline
\end{tabular}

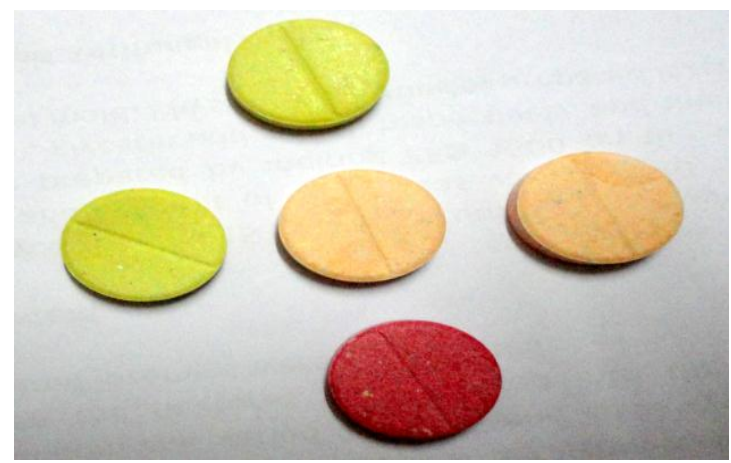




\section{Fig 1: Itraconazole Compressed tablet lozenge formulations}

\subsubsection{Formulation of soft lozenges}

- Hand-rolled lozenges

The binders used in these lozenges were acacia, gelatin and tragacanth at different concentrations. The powdered sugar and drug were sifted together and sufficient binder solution was gradually added to make a mass of the proper consistency. The mass was rolled into the shape of a cylinder and cut into 10 even sections (approximately twice the length of the diameter). Allowed to air dry (TABLES 4-6).

TABLE 4: FORMULATIONS OF HAND-ROLLED LOZENGES USING ACACIA AS BINDER

\begin{tabular}{ccccc}
\hline Ingredient & F15 & F16 & F17 & F18 \\
\hline Sucrose & $5 \mathrm{gm}$ & $5 \mathrm{gm}$ & $5 \mathrm{gm}$ & $5 \mathrm{gm}$ \\
Drug & $500 \mathrm{mg}$ & $500 \mathrm{mg}$ & $500 \mathrm{mg}$ & $500 \mathrm{mg}$ \\
Acacia mucilage & $10 \%$ & $15 \%$ & $20 \%$ & $25 \%$ \\
Water & q.s & q.s & q.s & q.s \\
Color & $2-3$ drops & $2-3$ drops & $2-3$ drops & q.s \\
Flavor & q.s & q.s & q.s \\
\hline
\end{tabular}

TABLE 5: FORMULATIONS OF HAND-ROLLED LOZENGES USING TRAGACANTH AS BINDER

\begin{tabular}{ccccc}
\hline Ingredient & F19 & F20 & F21 & F22 \\
\hline Sucrose & $5 \mathrm{gm}$ & $5 \mathrm{gm}$ & $5 \mathrm{gm}$ & $5 \mathrm{gm}$ \\
Drug & $500 \mathrm{mg}$ & $500 \mathrm{mg}$ & $500 \mathrm{mg}$ & $20 \%$ \\
Tragacanth mucilage & $10 \%$ & $15 \%$ & q.s & $25 \%$ \\
Water & q.s & q.s & q.s & $2-3$ drops \\
Color & $2-3$ drops & $2-3$ drops & q.s & q.s \\
Flavor & q.s & q.s & & \\
\hline
\end{tabular}

TABLE 6: FORMULATIONS OF HAND-ROLLED LOZENGES USING GELATIN AS BINDER

\begin{tabular}{|c|c|c|c|c|}
\hline Ingredient & F23 & F24 & F25 & F26 \\
\hline Sucrose & $5 \mathrm{gm}$ & $5 \mathrm{gm}$ & $5 \mathrm{gm}$ & $5 \mathrm{gm}$ \\
\hline Drug & $500 \mathrm{mg}$ & $500 \mathrm{mg}$ & $500 \mathrm{mg}$ & $500 \mathrm{mg}$ \\
\hline Gelatin solution & $2.5 \%$ & $5 \%$ & $7.5 \%$ & $10 \%$ \\
\hline Water & q.s & q.s & q.s & q.s \\
\hline Color & 2-3 drops & 2-3 drops & 2-3drops & 2-3 drops \\
\hline Flavor & q.s & q.s & q.s & q.s \\
\hline
\end{tabular}

- $\quad$ PEG-base lozenges

Blend the powders together until uniformly mixed. Melt PEG and add the powder mix to the molten base and blend thoroughly. Cool to less than $55^{\circ} \mathrm{C}$, add the flavor and mix well. Pour into troche molds and cool. They have to be stored under refrigeration. (TABLES 7-9) (Fig. 2)

TABLE 7: FORMULATIONS OF PEG-BASE LOZENGES WITH VARIABLE CONCENTRATIONS OF PEG 4000 AND PEG 400

\begin{tabular}{|c|c|c|c|c|c|c|c|c|c|}
\hline Ingredient & F27 & F28 & F29 & F30 & F31 & F32 & F33 & F34 & F35 \\
\hline $\begin{array}{l}\text { PEG 4000: } \\
\text { PEG } 400\end{array}$ & $10: 0$ & $9: 1$ & $8: 2$ & $7: 3$ & $6: 4$ & $5: 5$ & $4: 6$ & $3: 7$ & $2: 8$ \\
\hline Drug & $100 \mathrm{mg}$ & $100 \mathrm{mg}$ & $100 \mathrm{mg}$ & $100 \mathrm{mg}$ & $100 \mathrm{mg}$ & $100 \mathrm{mg}$ & $100 \mathrm{mg}$ & $100 \mathrm{mg}$ & $100 \mathrm{mg}$ \\
\hline Silica gel & $20 \mathrm{mg}$ & $20 \mathrm{mg}$ & $20 \mathrm{mg}$ & $20 \mathrm{mg}$ & $20 \mathrm{mg}$ & $20 \mathrm{mg}$ & $20 \mathrm{mg}$ & $20 \mathrm{mg}$ & $20 \mathrm{mg}$ \\
\hline Sweetener & $\begin{array}{c}1-2 \\
\text { drops }\end{array}$ & $\begin{array}{c}1-2 \\
\text { drops }\end{array}$ & 1-2 drops & 1-2 drops & $1-2$ drops & 1-2 drops & 1-2 drops & 1-2 drops & 1-2 drops \\
\hline Flavor & q.s & q.s & q.s & q.s & q.s & q.s & q.s & q.s & q.s \\
\hline Color & q.s & q.s & q.s & q.s & q.s & q.s & q.s & $\mathrm{q} \cdot \mathrm{s}$ & q.s \\
\hline
\end{tabular}

TABLE 8: FORMULATIONS OF PEG-BASE LOZENGES WITH VARIABLE CONCENTRATIONS OF ACACIA

\begin{tabular}{|c|c|c|c|c|c|c|c|}
\hline Ingredients & F36 & F37 & F38 & F39 & F40 & F41 & F42 \\
\hline PEG 1500 & $3 \mathrm{gm}$ & $3 \mathrm{gm}$ & $3 \mathrm{gm}$ & $3 \mathrm{gm}$ & $3 \mathrm{gm}$ & $3 \mathrm{gm}$ & $3 \mathrm{gm}$ \\
\hline Acacia & - & $50 \mathrm{mg}$ & $100 \mathrm{mg}$ & $150 \mathrm{mg}$ & $200 \mathrm{mg}$ & $250 \mathrm{mg}$ & $300 \mathrm{mg}$ \\
\hline Drug & $100 \mathrm{mg}$ & $100 \mathrm{mg}$ & $100 \mathrm{mg}$ & $100 \mathrm{mg}$ & $100 \mathrm{mg}$ & $100 \mathrm{mg}$ & $100 \mathrm{mg}$ \\
\hline Silica gel & $20 \mathrm{mg}$ & $20 \mathrm{mg}$ & $20 \mathrm{mg}$ & $20 \mathrm{mg}$ & $20 \mathrm{mg}$ & $20 \mathrm{mg}$ & $20 \mathrm{mg}$ \\
\hline Sweetener & 1-2 drops & 1-2 drops & 1-2 drops & 1-2 drops & 1-2 drops & 1-2 drops & 1-2 drops \\
\hline
\end{tabular}


Formulation, Evaluation And Characterization Of Itraconazole Lozenges

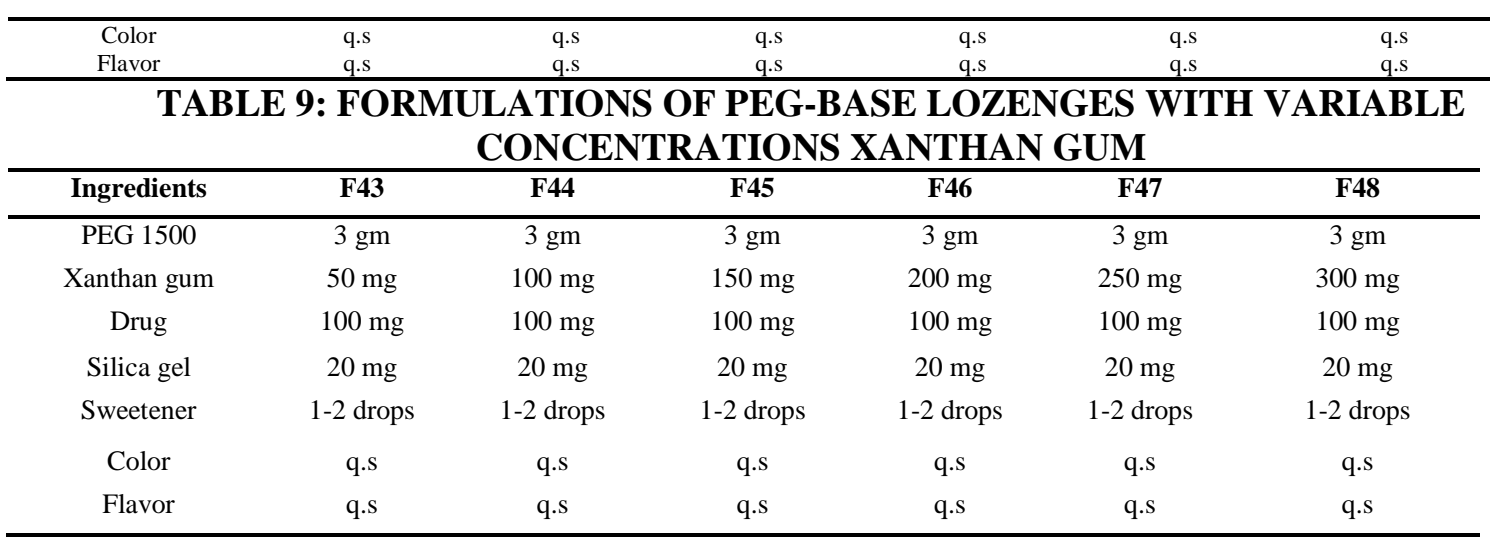

Fig 2: Itraconazole PEG-base soft lozenge formulations

\subsubsection{Evaluation and characterization}

The prepared lozenges were evaluated for parameters like flow properties of granules, weight variation, hardness, friability, thickness and diameter, disintegration time, drug content uniformity and drug-excipient compatibility studies (FTIR).

2.2.3.1 Weight variation

The weight variation was conducted by weighing 20 lozenges individually and calculating the average weight and comparing the individual lozenges weight to the average value.

2.2.3.2 Hardness

The hardness $\left(\mathrm{Kg} / \mathrm{cm}^{2}\right)$ of the prepared lozenges was determined using Monsanto hardness tester.

2.2.3.3 Thickness and diameter

Control of physical dimensions of the tablet such as thickness and diameter is essential for consumer acceptance and tablet uniformity. The thickness and diameter of the tablet was measured using screw gauge. It is measured in $\mathrm{mm}$.

2.2.3.4 Friability

Friability was determined using Roche friabilator. Speed of friabilator was set at $25 \mathrm{rpm}$. Pre-weighed tablets (6 tablets) were placed in the friabilator and it was subjected to 100 revolutions. The tablets were re-weighed and the percentage friability was calculated.

\subsubsection{Drug content}

Ten lozenges from each batch were selected and weighed individually and crushed in a mortar. Drug was extracted with $50 \mathrm{ml}$ of methanol. The drug content was determined spectrophotometrically at $262 \mathrm{~nm}$ with blank lozenge extract as the reference.

\subsubsection{Disintegration test}

The disintegration time of lozenges were determined by USP Disintegration apparatus and disintegration time was noted in $\mathrm{pH} 6.8$ phosphate buffer containing $2 \%$ SLS at $37^{\circ} \mathrm{C}$.

\subsubsection{In vitro dissolution studies}

In-vitro dissolution studies were carried out using USP dissolution test apparatus type II (paddle type) at $\quad 100 \mathrm{rpm}$ and $37 \pm 0.5^{\circ} \mathrm{C}$. $\mathrm{pH} 6.8$ buffer containing $2 \%$ SLS was used as dissolution medium for in vitro dissolution studies. A lozenge was placed in each flask of the dissolution apparatus and samples of $5 \mathrm{ml}$ were withdrawn at predetermined time intervals for $60 \mathrm{~min}$. In order to maintain sink conditions, an equal volume of medium was replaced. The samples were analyzed by using UV-Visible spectrophotometer at $262 \mathrm{~nm}$ and 
percentage drug released was calculated. This experiment was done in triplicate and the average percentage release was calculated.

2.2.3.8 Drug-excipient compatibility studies (FTIR)

Fourier transform infrared analysis was conducted to study the drug-excipient interactions Samples were scanned in the range from $400-4000 \mathrm{~cm}^{-1}$. The detector was purged carefully by clean dry helium gas to increase the signal level and reduce moisture.

\subsubsection{Antimicrobial activity}

This was determined in the agar diffusion medium employing Cup plate technique. Pure drug solution was used as standard. Drug extracted from formulations using methanol was used as test solution. The standard solution and the developed formulations (test solution) were taken into separate cups bored into sterile nutrient agar previously seeded with organism (Candida albicans). After allowing diffusion of solutions for two hours, the plates were incubated for $48 \mathrm{hrs}$ at $25^{\circ} \mathrm{C}$. The zone of inhibition (ZOI) was compared with that of the standard. The optimized formulation was tested in triplicate.

\subsubsection{Stability studies}

The stability studies of optimized formulations $\mathrm{F} 2$ and $\mathrm{F} 48$ were performed at $40^{\circ} \mathrm{C} \pm 2{ }^{\circ} \mathrm{C} / 75 \pm 5 \% \mathrm{RH}$ and $25^{\circ} \mathrm{C} \pm 2^{\circ} \mathrm{C} / 60 \pm 5 \% \mathrm{RH}$ respectively for 3 months. The formulations were examined visually for physical changes. The drug content was also determined at the end of every month for 3 months.

\section{Results And Discussion}

\subsection{Analytical method development}

3.1.1 Determination of $\lambda_{\max }$ of Itraconazole in methanol

The $\lambda_{\max }$ of Itraconazole in methanol was scanned. An absorption maximum of $262 \mathrm{~nm}$ was obtained.

3.1.2 Determination of $\lambda_{\max }$ of Itraconazole in $\mathrm{pH} 6.8$ phosphate buffer with various concentrations of SLS

All the scans with different concentrations of SLS showed absorption maximum around $262 \mathrm{~nm}$ which coincides with the absorption maxima value found in the literature. This shows that the solubility of Itraconazole in $\mathrm{pH} 6.8$ buffer was enhanced by the addition of SLS.

\subsection{Evaluation of lozenges}

\subsubsection{Compressed tablet lozenges}

The prepared Itraconazole lozenges were evaluated for their weight variation, hardness, friability, drug content uniformity and disintegration time. The percentage weight variation was within the specified IP limits and varied between $0.98 \%$ and $1.21 \%$. Hardness of the tablet was in the range of $5.5 \mathrm{~kg} / \mathrm{cm}^{2}$ to $13.5 \mathrm{~kg} / \mathrm{cm}^{2}$. Friability was less than $1 \%$ in all the batches, which indicates the tablet's ability to withstand shock during handling. Drug content was found to be in the range of $91.07 \%$ and $97.01 \%$. Disintegration time was found to be in the range of $35 \mathrm{~min}$ and $46 \mathrm{~min}$. It is clear from the above results that the evaluated parameters were within the limits. (TABLE 10)

TABLE 10: EVALUATION PARAMETERS OF ITRACONAZOLE COMPRESSED TABLET LOZENGES

\begin{tabular}{|c|c|c|c|c|c|c|}
\hline Formulations & $\begin{array}{c}\text { Weight } \\
\text { variation } \\
(\mathbf{n}=\mathbf{2 0})\end{array}$ & $\begin{array}{c}\text { Hardness } \\
\mathbf{K g} / \mathrm{cm}^{2} \\
(\mathbf{n}=3)\end{array}$ & $\begin{array}{c}\text { Thickness } \\
\text { mm } \\
(\mathbf{n}=\mathbf{3})\end{array}$ & $\begin{array}{c}\text { Friability }(\%) \\
(n=6)\end{array}$ & $\begin{array}{c}\text { Drug } \\
\text { content } \\
(\%)\end{array}$ & $\begin{array}{c}\text { Disintegration time } \\
(\text { min) }\end{array}$ \\
\hline F1 & 1.17 & 9.2 & 3.07 & 0.89 & 96.2 & 45 \\
\hline F2 & 1.13 & 10.3 & 3.01 & 0.97 & 94.5 & 51 \\
\hline F3 & 1.03 & 11.6 & 2.98 & 0.84 & 95.8 & 53 \\
\hline F4 & 1.05 & 12 & 3.17 & 0.16 & 96.7 & 56 \\
\hline F5 & 1.15 & 13 & 3.08 & 0.05 & 97.1 & 40 \\
\hline F6 & 0.98 & 13.5 & 3.05 & 0.12 & 95.8 & 41 \\
\hline F7 & 0.99 & 5.5 & 3.11 & 0.23 & 91.7 & 44 \\
\hline F8 & 1.11 & 6.2 & 3.10 & 0.18 & 93.3 & 46 \\
\hline F9 & 1.21 & 7.5 & 3.12 & 0.27 & 92.4 & 35 \\
\hline F10 & 1.18 & 8.3 & 2.98 & 0.65 & 94.5 & 42 \\
\hline F11 & 1.19 & 5.3 & 3.06 & 0.73 & 91.6 & 43 \\
\hline F12 & 1.16 & 6.3 & 2.99 & 0.54 & 93.5 & 43 \\
\hline F13 & 1.12 & 7.1 & 3.09 & 0.87 & 96.6 & 45 \\
\hline F14 & 1.09 & 7.5 & 3.14 & 0.82 & 92.9 & 44 \\
\hline
\end{tabular}

\subsubsection{Soft lozenges}


The prepared Itraconazole soft lozenges were evaluated for their weight variation, hardness, thickness, drug content uniformity and disintegration time. From the results obtained, it is clear that the physical parameters evaluated for different batches were within the specified IP limits. (TABLES 11-12)

TABLE 11: EVALUATION PARAMETERS OF HAND-ROLLED LOZENGES

\begin{tabular}{|c|c|c|c|c|}
\hline Formulations & Weight variation $(n=20)$ & Hardness $\left(\mathrm{kg} / \mathrm{cm}^{2}\right)$ & Drug content $(\%)$ & $\begin{array}{c}\text { Disintegration time } \\
\text { (min) }\end{array}$ \\
\hline F15 & 1.15 & 2.3 & 96.6 & 30 \\
\hline F16 & 1.12 & 2.5 & 93.8 & 31 \\
\hline F17 & 1.04 & 2.75 & 94.7 & 31 \\
\hline F18 & 1.06 & 2.8 & 96.7 & 32 \\
\hline F19 & 1.14 & 2.4 & 97.1 & 29 \\
\hline F20 & 0.98 & 2.56 & 96.8 & 30 \\
\hline F21 & 0.99 & 2.7 & 92.7 & 31 \\
\hline F22 & 1.12 & 2.8 & 92.3 & 31 \\
\hline F23 & 1.21 & 2.3 & 95.4 & 40 \\
\hline F24 & 1.19 & 2.5 & 94.5 & 45 \\
\hline F25 & 1.18 & 3.2 & 92.6 & 46 \\
\hline F26 & 1.17 & 3.9 & 97.5 & 47 \\
\hline
\end{tabular}

TABLE 12: EVALUATION PARAMETERS OF PEG-BASE LOZENGES

\begin{tabular}{|c|c|c|c|c|c|}
\hline Formulations & $\begin{array}{c}\text { Weight variation } \\
(\mathbf{n}=\mathbf{2 0})\end{array}$ & $\begin{array}{c}\text { Hardness } \\
\left(\mathrm{kg} / \mathrm{cm}^{2}\right)\end{array}$ & $\begin{array}{l}\text { Thickness } \\
\text { mm }(n=3)\end{array}$ & $\begin{array}{c}\text { Drug content } \\
(\%)\end{array}$ & $\begin{array}{c}\text { Disintegration time } \\
\text { (min) }\end{array}$ \\
\hline F27 & 1.28 & 3.9 & 5.17 & 96.1 & 20 \\
\hline F28 & 1.35 & 3.6 & 5.26 & 94.5 & 18 \\
\hline F29 & 2.8 & 3.1 & 5.01 & 95.8 & 15 \\
\hline F30 & 3.5 & 2.8 & 5.21 & 96.4 & 13 \\
\hline F31 & 4.1 & 2.3 & $4 . .99$ & 97.12 & 12 \\
\hline F32 & 3.6 & 1.9 & 5.23 & 95.69 & 9 \\
\hline F33 & 1.12 & 1.2 & 4.98 & 91.54 & 7 \\
\hline F34 & - & - & - & - & - \\
\hline F35 & - & - & - & - & - \\
\hline F36 & 1.12 & 2.1 & 5.15 & 94.5 & 12 \\
\hline F37 & 1.04 & 2.9 & 5.13 & 91.06 & 15 \\
\hline F38 & 1.06 & 3.1 & 5.16 & 93.06 & 18 \\
\hline F39 & 1.14 & 3.41 & 5.11 & 96.65 & 20 \\
\hline F40 & 0.98 & 3.63 & 5.17 & 95.4 & 22 \\
\hline F41 & 0.99 & 3.74 & 5.23 & 92.1 & 25 \\
\hline F42 & 1.12 & 3.8 & 5.19 & 94.3 & 26 \\
\hline F43 & 1.21 & 2.9 & 5.24 & 95.6 & 20 \\
\hline F44 & 1.19 & 3.3 & 5.22 & 92.3 & 26 \\
\hline F45 & 1.18 & 3.6 & 5.19 & 93.7 & 30 \\
\hline F46 & 1.17 & 3.75 & 5.20 & 95.6 & 33 \\
\hline F47 & 0.96 & 4.2 & 5.16 & 96.1 & 37 \\
\hline F48 & 1.12 & 4.5 & 5.14 & 95.65 & 45 \\
\hline
\end{tabular}

3.2.3 In vitro dissolution studies

Based on the in vitro drug release studies, two formulations, F2 and F48 were optimized. They showed a cumulative percentage drug release of $89.60 \%$ and $90.45 \%$ respectively by the end of 60 min. (TABLE 13) (Fig. 3-4)

TABLE 13: DRUG RELEASE PROFILE OF OPTIMIZED FORMULATIONS

\begin{tabular}{cccc}
\hline Time (min) & \multicolumn{2}{c}{ Cumulative percentage drug released } \\
\cline { 2 - 4 } 10 & F2 & F48 \\
20 & 11.21 & 28.7 & 43.6 \\
30 & 17.85 & 50.1 & 74.34 \\
40 & 25.76 & 85.67 \\
50 & 41.54 & 50.45 \\
\hline
\end{tabular}



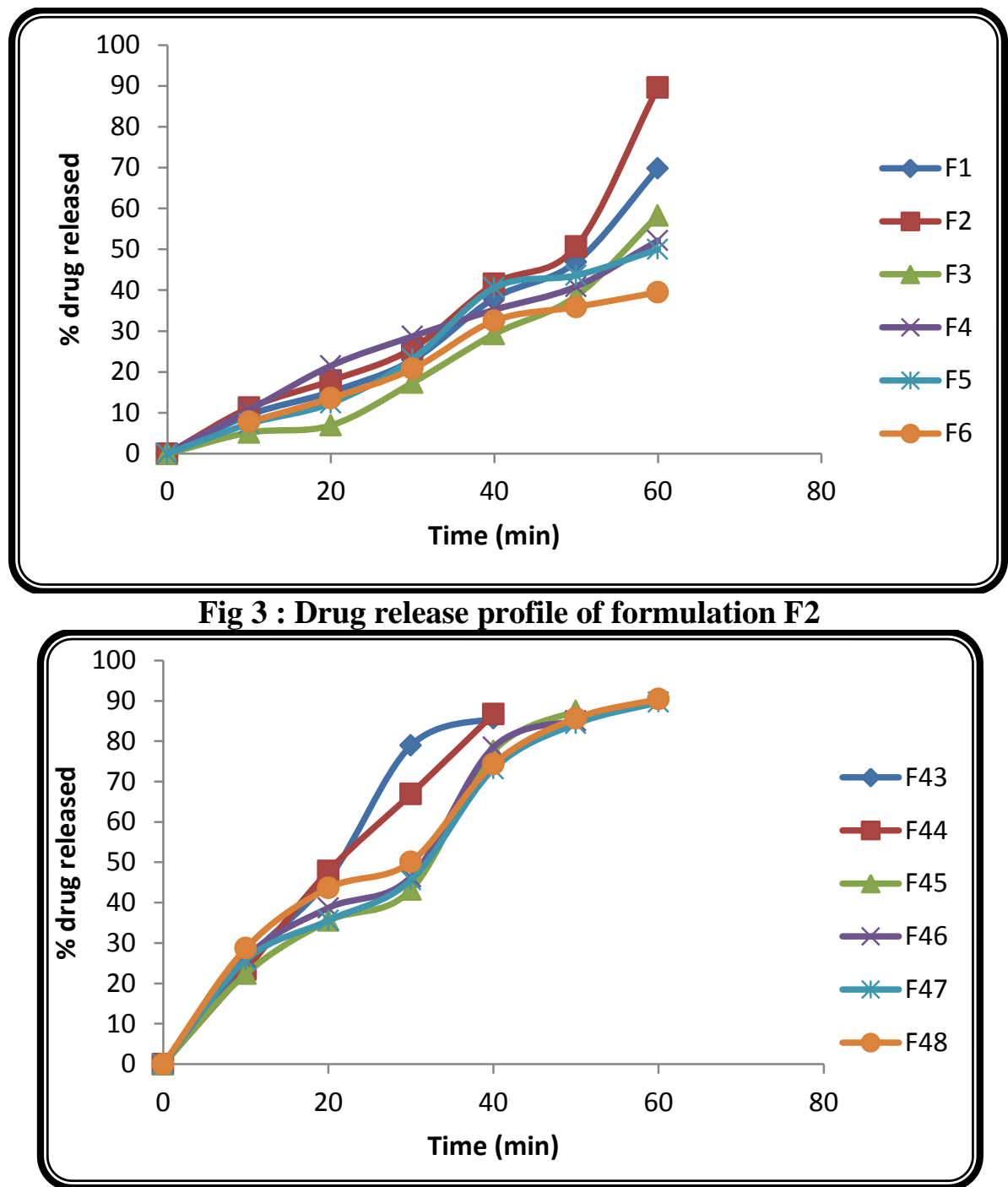

Fig 4: Drug release profile of formulation F48

\subsubsection{Drug-excipient compatibility studies}

The IR spectrum of the formulation F2 and formulation F48 recorded by FTIR spectrometer which are compared with standard functional group frequencies of Itraconazole. The characteristic peaks of the optimized formulations followed the same trajectory as that of the drug alone with minor differences. Thus there may be no drug-excipient interactions.

\subsubsection{Antimicrobial activity}

The optimized formulations showed antifungal activity when tested microbiologically by the CupPlate technique using drug solution as standard. The results obtained are as shown in Fig. 5 and 6.

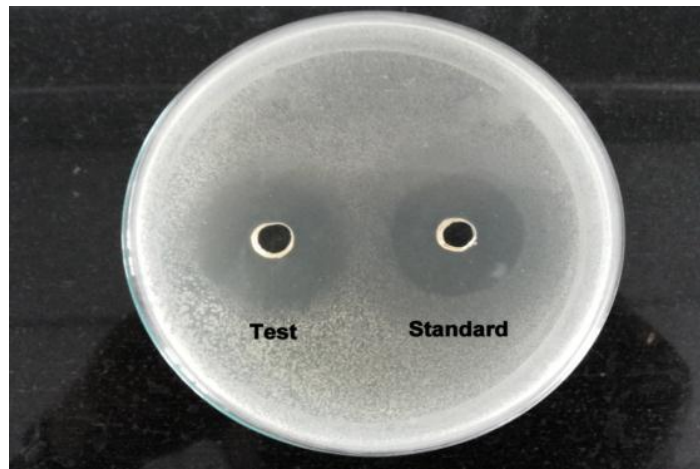

Fig 5: Zone of inhibition of formulation F2 


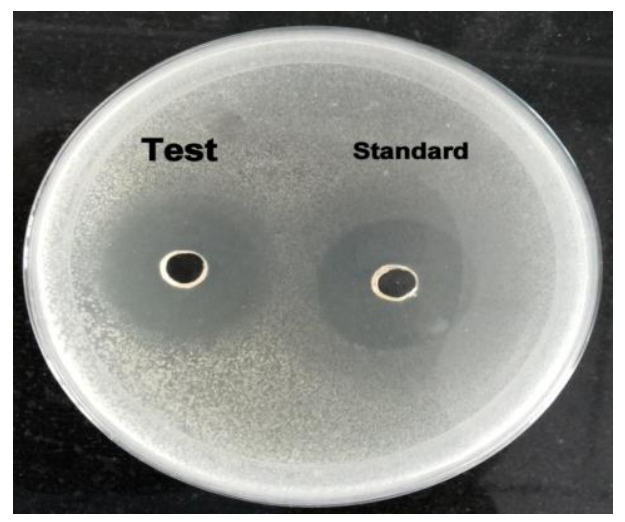

Figure 6: Zone of inhibition of formulation F48

\subsubsection{Stability studies}

It was observed that there was no change in the physical appearance of the formulation. The drug content was analyzed and the results were found to be in the range within the limits as per IP and ICH guidelines. The stability data of formulation F2 and F48 are illustrated in the tables. As observed from the data shown in the tables, the formulations showed no significant changes in the drug content, hardness, friability and in vitro drug release profiles. Hence, it is confirmed that the formulations were stable at elevated temperatures. (TABLES 14-16)

TABLE 14-16: STABILITY DATA OF OPTIMIZED FORMULATIONS TABLE 14

\begin{tabular}{ccccccc}
\hline Time interval & \multicolumn{2}{c}{ Hardness } & \multicolumn{2}{c}{ Friability } & \multicolumn{2}{c}{ Drug content } \\
\cline { 2 - 7 } & F2 & F48 & F2 & F48 & F2 & F48 \\
After 1 month & 10.1 & 4.31 & 0.97 & - & 96.51 & 96.98 \\
After 2 months & 9.9 & 4.22 & 1.12 & - & 96.42 & 96.65 \\
After 3 months & 9.8 & 4.16 & 1.13 & - & 96.21 & 95.87 \\
\hline
\end{tabular}

TABLE 15

\begin{tabular}{cccc}
\hline Time (min) & \multicolumn{3}{c}{ Cumulative percentage drug released } \\
\cline { 2 - 4 } 10 & 1 month & 2 months & 3 months \\
20 & 10.21 & 9.92 & 9.04 \\
30 & 16.85 & 15.43 & 14.97 \\
40 & 24.76 & 23.76 & 22.45 \\
50 & 41.45 & 40.76 & 40.21 \\
60 & 50.41 & 50.01 & 49.97 \\
\hline
\end{tabular}

TABLE 16

\begin{tabular}{cccc}
\hline Time (min) & \multicolumn{3}{c}{ Cumulative percentage drug released } \\
\cline { 2 - 4 } 10 & 1 month & 2 months & 3 months \\
20 & 28.21 & 27.92 & 4.04 \\
30 & 42.85 & 42.43 & 41.97 \\
40 & 49.76 & 48.76 & 78.45 \\
50 & 73.45 & 72.76 & 72.21 \\
60 & 85.41 & 85.01 & 84.97 \\
\hline
\end{tabular}

\section{Conclusion}

Rationale of the study was to develop Itraconazole lozenges for topical therapy of oropharyngeal candidiasis. Topical application of drug prevents several drug interactions and lozenge is a better delivery system as the effective concentration of drug can be maintained in the oral cavity for a more prolonged period of 
time. Different types of Itraconazole lozenges were formulated and the formulations were evaluated for weight variation, hardness, drug content uniformity and disintegration time. In vitro drug release studies were carried out using USP dissolution apparatus type II. Two formulations, F2 and F48 were optimized based on in vitro drug release studies. The optimized formulations were also subjected to drug-excipient interaction studies, microbial studies and stability studies.

The lozenges were optimized by all the above parameters and the following conclusions were made from the studies.

- No drug-excipient interactions were seen.

- The formulations were stable for 3 months and no significant drug degradation was observed.

- The formulations had sufficient antimycotic activity.

It can be stated that the objective of the study was met. Itraconazole lozenges were successful in delivering the drug for topical application.

\section{References}

[1]. Joel B. Epstein, Bruce Polsky, Oropharyngeal Candidiasis: A Review of Its Clinical Spectrum and Current Therapies, Clinical therapeutics, 20(1), 1998, 40-57.

[2]. Patricia A. Murray, Susan L Koletar, Irma Mallegoh, Jane Wu, Bruce L. Moskovitz, Itraconazole Oral Solution Vs Clotrimazole Troches for the Treatment of Oropharyngeal Candidiasis in Immuno-compromised Patients, Clinical therapeutics, 19(3), 1997, 471480.

[3]. Lakshman P. Samaranayake, Martin M. Ferguson, Delivery of antifungal agents to the oral cavity, Advanced Drug Delivery Reviews, 13, 1994, 161-179.

[4]. Stephen Fowler, David S. Jones, Modified adherence of Candida albicans to human buccal epithelial cells in vitro following treatment with cationic, non-antibiotic antimicrobial agents. International Journal of Pharmaceutics, 86, 1992, 193-199.

[5]. J.-M. Cardot, C. Chaumont, C. Dubray, D. Costantini, J.-M. Aiache, Comparison of the pharmacokinetics of Miconazole after administration via a bioadhesive slow release tablet and an oral gel to healthy male and female subjects, British Journal of Clinical Pharmacology, 10, 2004, 1365-2125.

[6]. Loyd V. Allen, Jr. Troches and Lozenges, Secundum Artem-Current \& Practical Compounding Information for the Pharmacist. 4(2).

[7]. Rajesh Kini, Mahalaxmi Rathnanand, Deepak Kamath, Exploring the use of Isomalt as the tooth friendly sugar substitute in the formulation of Salbutamol sulfate compressed tablet lozenges, International Journal of PharmTech Research, 3(3), 2011, 13751381.

[8]. Nagoba Shivappa N., Purushotham Rao K., Zakaullah S, Formulation of Clotrimazole as lozenge tablet for improved delivery to oral thrush, Journal of Pharmaceutical and Biomedical Sciences, 12(17), 2011, 1-4.

[9]. Dharmajit Pattanayak, Saumya Das, Formulation Development and Optimization of Medicated Lozenges for Pediatric Use, International Journal of Pharmaceutical Science and Research, 3(1), 2012, 138-140.

[10]. Nagoba S N, Rao K P, Sameer S, Gujarathi D S, Nagoba B S, Studies on Candy Based Ketoconazole Pediatric Tablet Lozenges, International Journal of Research in Ayvrveda and Pharmacy, 2(1), 2011, 239-243. 